\title{
Comparison of three molecular methods for the detection of Pilchard herpesvirus in archived paraffin-embedded tissue and frozen tissue
}

\author{
Melanie Crockford ${ }^{1,2, *}$, J. Brian Jones ${ }^{1}$, Kenneth McColl $^{3}$, Richard J. Whittington ${ }^{4}$ \\ ${ }^{1}$ Department of Fisheries Western Australia, 39 Northside Drive, Hillarys, Western Australia 6025, Australia \\ ${ }^{2}$ Murdoch University, South Street, Murdoch, Western Australia 6150, Australia \\ ${ }^{3}$ CSIRO Livestock Industries, Australian Animal Health Laboratory, PO Bag 24, Geelong, Victoria 3220, Australia \\ ${ }^{4}$ University of Sydney, 425 Werombi Road, Camden, New South Wales 2570, Australia
}

\begin{abstract}
Two epizootics affecting pilchards Sardinops sagax neopilchardus have been observed over their entire geographical range off the Australian coastline. The first occurred in 1995, involving high mortality (at least $10 \%$ ) that devastated the pilchard population. The second occurred in 1998 and involved even higher mortality $(70 \%)$. Both epizootics moved rapidly against the prevailing Leeuwin and East Australian currents from a defined point of origin. A herpesvirus, pilchard herpesvirus (PHV), was determined to be the cause of the epizootics, but the source of the virus remains unknown. In this research, in situ hybridization (ISH), polymerase chain reaction (PCR), and realtime PCR were compared for the detection of PHV in archived paraffin-embedded tissue and frozen tissue collected before, during, and after the 1995 epizootic. Results show that the conventional PCR failed to detect PHV in archived paraffin-embedded tissue, and that real-time PCR was the most sensitive of the 3 techniques and the best method for the detection of PHV.
\end{abstract}

KEY WORDS: PHV $\cdot$ Epizootic $\cdot$ Real-time PCR $\cdot$ PCR $\cdot$ ISH

\section{INTRODUCTION}

In 1995 and again in 1998, millions of pilchards Sardinops sagax neopilchardus were found dead or dying off the coast of Australia. An estimated $70 \%$ of the pilchard population was infected in the 1998 epizootic (Gaughan et al. 2000), where the disease spread in a wave-like manner with pilchards at the wave front being the most severely affected. Models have been proposed to explain how the virus spread so quickly. The most recent research proposed that the schooling patterns of pilchards, involving contact within and also between schools, allowed the rapid spread of the disease from a point source (Murray et al. 2003). During the disease outbreak, affected pilchards were observed to exhibit signs of stress only a few minutes before dying (Whittington et al. 1997), allowing infected and uninfected fish to school together (Murray et al. 2003).
The causative agent was identified as an uncharacterized virus, Pilchard herpesvirus (PHV; Hyatt et al. 1997, Whittington et al. 1997). It has been hypothesized that the virus could have already been present within the Australian pilchard population prior to 1995, and that some factor(s) triggered the onset of disease. Alternatively, as South Australia was the origin of each epizootic, the virus could have been introduced to Australian waters in both 1995 and 1998 through the importation of pilchards into South Australia to feed seacaged southern bluefin tuna Thunnus maccoyii (Griffin et al. 1997, Whittington et al. 1997, Gaughan et al. 2000).

Little is known of the pathogenesis of this viral infection. The incubation period from viral infection to onset of clinical disease is uncertain, but based on lesion development in a longitudinal study it was estimated as approximately $4 \mathrm{~d}$ (Whittington et al. 1997). At the time of the first reported mortality in 1995, a range of samples 
was collected and examined by histology (Whittington et al. 1997). Samples included pilchards collected before the onset of mortality, those in the heart of the mortality front, and pilchards collected several days after the front had passed. Electron microscopy studies of these samples revealed that virus was only present in samples from fish showing clinical signs of disease; no virus particles were seen in samples from fish that appeared healthy (Hyatt et al. 1997). After the 1995 outbreak, it was suggested that fish collected $4 \mathrm{~d}$ before the onset of local pilchard deaths were apparently healthy, but that mild focal lesions in the gills became generalized over the ensuing $4 \mathrm{~d}$ (Whittington et al. 1997). Pilchards surviving the epizootic had lesions consistent with infection by PHV. This suggested that they had survived, rather than avoided, infection (Murray et al. 2003). These survivors showed few signs of disease $8 \mathrm{~d}$ after the front had passed (Whittington et al. 1997). Modeling by Murray et al. (2003) suggested the incubation period of infection to be 4 to $12 \mathrm{~d}$, depending on the epidemic-wave speed.

Attempts to culture PHV on cell lines have been unsuccessful (Hyatt et al. 1997). Additional techniques are needed to further characterize the virus, including techniques that can detect virus in formalin-fixed and paraffin-embedded tissues and frozen tissues, as these are the only samples available. In 2005, some sequence data for PHV were entered into GenBank, and a PCR for the detection of PHV was described (Crockford et al. 2005) although this only produced $373 \mathrm{bp}$ of sequence data. Another 2 molecular diagnostic methods have now also been developed, including real-time PCR and in situ hybridization (ISH). Here we compared the 3 molecular methods, i.e. ISH, PCR, and realtime $\mathrm{PCR}$, for detecting $\mathrm{PHV}$ in archived paraffinembedded or frozen tissues from fish collected before, during, and after the 1995 outbreak.

\section{MATERIALS AND METHODS}

Fish stocks. The samples used in this study were examined previously by histopathology and are listed in Table 1. Fish were chosen based on time of collec- tion and the results of the histopathological findings, with the aim of testing a range of fish: healthy preepizootic (sample number 95-4667); healthy, but with mild lesions (95-5000); severe lesions (95-4420); and healthy post-epizootic (95-5135). Fish showing mild histological changes and collected as the mortality front was approaching (95-5000) were also included in this study to determine if any of the methods can detect the assumed low level of infection in these samples.

Wherever possible, histopathology as well as ISH, PCR, and real-time PCR were undertaken on all samples, but in some instances suitable tissues were not available for histopathology and ISH. Between 3 and 6 fish from each group were tested depending on availability.

DNA extraction from frozen tissue. A modified DNAzol (Life Technologies) procedure was used to extract DNA from frozen tissue (Crockford et al. 2005).

DNA extraction from paraffin-embedded blocks for

PCR. Protocols to avoid cross-contamination between samples during preparation were rigorously observed. Two sections were cut per block at $12 \mu \mathrm{M}$ each and placed in a sterile $1.5 \mathrm{ml}$ screw-cap tube.

To eliminate contamination problems, DNA extraction was never undertaken on more than one suspectpositive sample on any one day. Each tube was centrifuged at $16000 \times g$ for $1 \mathrm{~min}$ at ambient temperature to pellet the tissue, and $200 \mu \mathrm{l}$ sterile water and $0.5 \%$ v/v $(1 \mu \mathrm{l})$ Tween 20 were added. Each tube was boiled for $10 \mathrm{~min}$, frozen in liquid nitrogen for $5 \mathrm{~min}$, boiled for $10 \mathrm{~min}$, frozen in liquid nitrogen for $5 \mathrm{~min}$, and finally boiled for $10 \mathrm{~min}$. The sample was centrifuged at $3000 \times g$ for $20 \mathrm{~min}$ at ambient temperature, and the supernatant was transferred to a fresh sterile tube. The resultant solution contained milky strands and was therefore unsuitable for DNA quantification by spectrometry. For this reason, undiluted, 1:10, and, on one occasion, 1:100 dilutions of each sample were used directly in the PCR to provide a range of template concentrations. The extracted DNA samples were stored at $-20^{\circ} \mathrm{C}$.

Production of a positive control for PCR and realtime PCR optimization. A PCR was performed on a

Table 1. Sardinops sagax neopilchardus. Previously determined histopathological results of samples of a group of pilchards that were used in this study. Samples were either frozen or fixed tissues

\begin{tabular}{|c|c|c|c|c|}
\hline Sample & $\begin{array}{c}\text { Location of } \\
\text { sample collection }\end{array}$ & $\begin{array}{l}\text { Collection in relation } \\
\text { to } 1995 \text { epizootic }\end{array}$ & $\begin{array}{l}\text { Status at time } \\
\text { of collection }\end{array}$ & $\begin{array}{l}\text { Histological } \\
\text { examination }\end{array}$ \\
\hline $95-4667$ & Iluka & Pre-epizootic (4 d before) & Healthy, live & No significant changes \\
\hline $95-5000$ & Iluka & $\begin{array}{l}\text { Just before mortality } \\
\text { front ( } 2 \mathrm{~d} \text { before) }\end{array}$ & Affected, live & $\begin{array}{l}\text { Slight changes, which may } \\
\text { be consistent with viral infection }\end{array}$ \\
\hline $95-4420$ & Port Stephens & During epizootic & Affected, moribund & $\begin{array}{l}\text { Marked changes. Severe } \\
\text { hyperplasia of the gill epithelium }\end{array}$ \\
\hline $95-5135$ & Iluka & Post-epizootic (8 d after) & Healthy, live & No significant changes \\
\hline
\end{tabular}


known PHV-positive DNA sample using the PHV373 protocol (Crockford et al. 2005). PCR product was extracted, purified, and cloned into TA cloning vector pCR2.1 (Qiagen), following the manufacturer's instructions. A PHV-positive clone was chosen and grown in Luria-Bertani (LB) broth overnight, and plasmid extractions were performed using GenElute Plasmid Miniprep Kit (Catalogue \#PLN-70, Sigma) and the recommended protocol. This clone was used as a positive control for PCR and real-time PCR.

ISH. Samples used for ISH were from fish that had been collected pre-, just before, during, and postepizootic (Table 1). Tissues from these fish were fixed in formalin and embedded in paraffin for histopathological and ISH testing. Appropriate controls were included with each test. The negative control consisted of formalin-fixed and paraffin-embedded (FFPE) tissue from a negative control fish (C1-2) from a transmission trial carried out in 1999. The positive control consisted of gill tissue from frozen fish (95-4420) freshly fixed in formalin and then paraffin-embedded.

Samples used for ISH optimization: Sample 95-4420 that showed histological lesions suggestive of PHV and was strongly PHV-positive by PCR was used as a positive control for the optimization of the ISH. Gill tissue from this fish was from FFPE blocks. PCR product was used to make a PHV-specific riboprobe (see below).

The sensitivity of the PHV ISH was not determined due to the unavailability of suitable material. The specificity of the ISH was tested against all available controls. The positive control consisted of PHV riboprobe applied to a known PHV-positive pilchard gill section (as determined by PCR). Negative controls included $\mathrm{PHV}$ riboprobe applied to yellowhead virus (YHV)positive prawn section, a whitespot syndrome virus (WSV)-positive prawn section, a PHV-negative pilchard gill section, and a salmon gill section showing an inflammatory response. In addition, a WSV riboprobe and a YHV riboprobe were applied to a PHV-positive gill section.

Riboprobe production: Four $\mu \mathrm{l}$ of PHV PCR product were made up to $9.5 \mu \mathrm{l}$ with sterile water and used in a riboprobe reaction mix, consisting of $4 \mu$ of $5 \times$ transcription buffer, $2 \mu \mathrm{l}$ of $100 \mathrm{mM}$ dithiothreitol (DTT), $3 \mu \mathrm{l}$ RNA labeling mix (Boehringer-Mannheim), $1 \mu \mathrm{l}$ of SP6 RNA polymerase, and $0.5 \mu \mathrm{l}$ of RNAsin. The reaction mix was incubated at $37^{\circ} \mathrm{C}$ for $2 \mathrm{~h}$, followed by the addition of $2 \mu \mathrm{l}$ of $0.2 \mathrm{M}$ EDTA ( $\mathrm{pH} 8.0$ ) to stop the reaction. Labeled RNA was incubated at $-80^{\circ} \mathrm{C}$ for $30 \mathrm{~min}$ with $2.5 \mu$ l of $4 \mathrm{M}$ lithium chloride and $75 \mu$ of $100 \%$ ethanol to precipitate the labeled RNA. Following centrifugation at $10000 \times g$ for $20 \mathrm{~min}$, the resulting pellet was washed in $70 \%$ ethanol, centrifuged at $10000 \times g$ for $15 \mathrm{~min}$, and dried following decanting of the supernatant. The pellet was then resuspended in $100 \mu \mathrm{l}$ of sterile water. Ten $\mu$ l of the preparation were run on a $1.5 \%$ agarose gel at 90 volts for 50 min to check the quality of the riboprobe. One $\mu \mathrm{l}$ of RNAsin was added to the resuspended labeled RNA, and the preparation was stored in $5 \mu \mathrm{l}$ aliquots at $-80^{\circ} \mathrm{C}$.

Preparation of sections for ISH: Paraffin-embedded tissues were sectioned at $5 \mu \mathrm{M}$ thickness onto silanated slides and allowed to dry. Sections were then deparaffinized in 2 stages of xylene for $5 \mathrm{~min}$ at each stage. They were rehydrated in $95 \%$ ethanol for $5 \mathrm{~min}, 70 \%$ ethanol for $5 \mathrm{~min}$, and finally in Milli-Q (MQ) water for 5 min.

Hybridization of riboprobe to tissue sections: Protease VIII (300 $\mu \mathrm{l})$ diluted in buffer 1 (100 mM Tris- $\mathrm{HCl}$ $\mathrm{pH} 7.5,150 \mathrm{mM} \mathrm{NaCl}$ ) to a concentration of $375 \mathrm{ng}^{-1}$ was applied to each section and incubated at $37^{\circ} \mathrm{C}$ for $20 \mathrm{~min}$ in an airtight humid container. Following incubation, the sections were washed in MQ water, soaked in $95 \%$ ethanol, and left to air dry.

A stock solution of hybridization mixture was prepared consisting of $5 \mathrm{ml}$ formamide, $1 \mathrm{ml}$ dextran sulfate in sterile water (stock solution of $2 \mathrm{~g}$ dextran sulfate in $4 \mathrm{ml}$ sterile water), and $1 \mathrm{ml}$ of $20 \times \mathrm{SSC}(175.3 \mathrm{~g}$ $\mathrm{NaCl}, 88.2 \mathrm{~g}$ sodium citrate, $800 \mathrm{ml}$ sterile water, with the final solution adjusted to $\mathrm{pH} 7.0$ with $\mathrm{HCl}$ and made up to $1 \mathrm{l}$ ). Hybridization solution (100 $\mu \mathrm{l}$ per section) was freshly prepared using $70 \mu$ l hybridization mixture (previously prepared), $4 \mu \mathrm{l}$ freshly denatured salmon sperm DNA at $10 \mathrm{mg} \mathrm{ml}^{-1}, 25.5 \mu \mathrm{l}$ of TE8 buffer (10 mM Tris- $\mathrm{HCl} \mathrm{pH} 8.0,1 \mathrm{mM}$ EDTA $\mathrm{pH}$ 8.0), and $0.5 \mu \mathrm{l}$ of riboprobe previously prepared by in vitro transcription of PCR product. Before application to the section, the hybridization solution was vortexed, placed on a heating block at $100^{\circ} \mathrm{C}$ for $10 \mathrm{~min}$ to denature the probe, and then placed on ice ready to use. Of this solution $100 \mu \mathrm{l}$ was applied per section, and the section was coverslipped. The section was then heated to approximately $95^{\circ} \mathrm{C}$ for $10 \mathrm{~min}$ to denature the nucleic acid in the tissue. Sections were then quickly placed in a humidified air-tight container pre-warmed to $50^{\circ} \mathrm{C}$ and moistened with $4 \times \mathrm{SSC}$ ( $200 \mathrm{ml}$ of $20 \times \mathrm{SSC}$ in $11 \mathrm{MQ}$ water), and incubated in a pre-heated oven at $50^{\circ} \mathrm{C}$ for $2.5 \mathrm{~h}$ to allow hybridization of the probe to viral nucleic acid in the section.

Following hybridization, coverslips were carefully washed off with $4 \times \mathrm{SSC}$, the sections then washed in $4 \times \mathrm{SSC}$ for $2 \times 5 \mathrm{~min}$, washed in $1 \times \mathrm{SSC}(50 \mathrm{ml}$ of $20 \times$ $\mathrm{SSC}$ in $11 \mathrm{MQ}$ water) for $2 \times 5 \mathrm{~min}$, and then washed in $0.1 \times \mathrm{SSC}(5 \mathrm{ml}$ of $20 \times \mathrm{SSC}$ in $1 \mathrm{l} \mathrm{MQ}$ water) that was previously heated to approximately $80^{\circ} \mathrm{C}$, for $15 \mathrm{~min}$ at ambient temperature.

Blocking solution (3\% skim milk powder and 0.05\% Triton-X-100 in $5 \mathrm{ml}$ buffer 1) was applied to the sections at ambient temperature for $30 \mathrm{~min}$ in a humidified air-tight container. Sheep anti-digoxigenin (DIG) 
antibody conjugated to alkaline phosphatase (Boehringer-Mannheim) was diluted 1:500 in the previously prepared blocking solution and applied at $300 \mu \mathrm{l}$ per section, and left overnight at $4^{\circ} \mathrm{C}$ in a humidified airtight container.

The sections were washed in buffer 1 for $2 \times 5 \mathrm{~min}$ and then immersed in buffer $3(100 \mathrm{mM}$ Tris- $\mathrm{HCl} \mathrm{pH}$ 9.5, $100 \mathrm{mM} \mathrm{NaCl}$ and $50 \mathrm{mM} \mathrm{MgCl}_{2}$ ) for at least 2 min at ambient temperature. NBT/BCIP color development solution (Boehringer-Mannheim), diluted 1:50 in buffer 3, was applied at $300 \mu$ per section and left in darkness for at least $2 \mathrm{~h}$, with the reaction monitored after $2 \mathrm{~h}$ for determination of the end point. Immersing in 2 changes of $\mathrm{MQ}$ water stopped the reaction.

The section was counterstained by applying $0.5 \%$ Bismark brown for $60 \mathrm{~s}$, rinsed in running tap water, and then dipped twice in acetone to remove nonspecific staining. The section was further dehydrated using standard methods before being mounted in
DePeX. Each section was examined by light microscopy for the presence of hybridized dark blue probe against a light brown background.

PCR for the detection of PHV. The PHV373 PCR used to detect PHV has been described previously (Crockford et al. 2005). The sensitivity of the PCR was determined using a PHV clone. DNA added for sensitivity testing ranged from $366 \mathrm{ng}^{-1}$ as a neat solution to

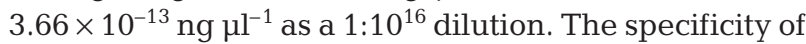
the PCR was tested using DNA extractions of 27 known PHV-negative samples including DNA extracts from other piscine herpesviruses, with 2 PHV-positive control samples, identical to those listed in Table 2.

All samples were tested by PCR; however, some samples were from FFPE blocks and others were freshly extracted DNA samples from frozen fish. DNA extractions for PCR from frozen gill tissue of samples 95-4420 (6 fish), 95-4667 (6 fish), and 95-5135 (6 fish) were performed using the method described by Crock-

Table 2. Real-time PCR specificity results, including a range of known negative samples and 2 PHV positive samples, as tested by the conventional PHV373 PCR. Only the 2 known PHV-positive samples were positive and all known PHV-negative samples were negative by this testing. VHSV: viral hemorrhagic septicemia virus; OMV: Oncorhynchus masou virus; WSHV1: white sturgeon herpesvirus 1; WSHV2: white sturgeon herpesvirus 2; KHV: koi herpesvirus; GFHNV: goldfish hematopoietic necrosis virus; AAHL: samples were obtained from the CSIRO Australian Animal Health Laboratories; WA: samples were obtained from the Fish Health Laboratory, Department of Fisheries WA, Western Australia

\begin{tabular}{|c|c|c|c|c|}
\hline Tube \# & Sample description & $\mathrm{C}_{\mathrm{t}}$ value & Melt curve analysis & Interpretation \\
\hline 1 & VHSV known positive (AAHL) & 0 & Negative & Negative \\
\hline 2 & OMV known positive (AAHL) & 0 & Negative & Negative \\
\hline 3 & WSHV1 known positive (AAHL) & 0 & Negative & Negative \\
\hline 4 & WSHV2 known positive (AAHL) & 0 & Negative & Negative \\
\hline 5 & PHV known positive (AAHL) & 25.5 & Positive (83.0) & Positive \\
\hline 6 & KHV \#1 (plasmid containing KHV DNA imported from Indonesia) & a) 0 & Negative & Negative \\
\hline 7 & KHV \#2 (plasmid containing KHV DNA imported from Indonesia) & ) 0 & Negative & Negative \\
\hline 8 & Suspect KHV positive (not confirmed) (WA) & 0 & Negative & Negative \\
\hline 9 & Suspect KHV positive (not confirmed) (WA) & 0 & Negative & Negative \\
\hline 10 & GFHNV positive (WA) (kidney) & 0 & Negative & Negative \\
\hline 11 & GFHNV positive (WA) (spleen) & 0 & Negative & Negative \\
\hline 12 & GFHNV positive (WA) (kidney, spleen) & 0 & Negative & Negative \\
\hline 13 & GFHNV positive (WA) (kidney, spleen, liver) & 0 & Negative & Negative \\
\hline 14 & FH05-080 \#1 Whiting ${ }^{\mathrm{a}}$ & 0 & Negative & Negative \\
\hline 15 & FH05-080 \#2 Whiting ${ }^{\text {a }}$ & 0 & Negative & Negative \\
\hline 16 & FH05-080 \#3 Whiting ${ }^{\text {a }}$ & 0 & Negative & Negative \\
\hline 17 & FH05-080 \#4 Whiting ${ }^{\mathrm{a}}$ & 0 & Negative & Negative \\
\hline 18 & FH05-081 \#1 Herring ${ }^{b}$ & 0 & Negative & Negative \\
\hline 19 & FH05-081 \#2 Herring ${ }^{b}$ & 0 & Negative & Negative \\
\hline 20 & FH05-081 \#3 Herring ${ }^{b}$ & 0 & Negative & Negative \\
\hline 21 & FH05-081 \#4 Herring ${ }^{b}$ & 0 & Negative & Negative \\
\hline 22 & FH05-082 Baitfish (Spratelloides robustus) & 0 & Negative & Negative \\
\hline 23 & FH05-083 Tin sardine Sardinops sagax & 0 & Negative & Negative \\
\hline 24 & FH05-085 \#1 Indonesian pilchard ${ }^{c}$ & 0 & Negative & Negative \\
\hline 25 & FH05-085 \#2 Indonesian pilchard ${ }^{\mathrm{c}}$ & 0 & Negative & Negative \\
\hline 26 & FH05-085 \#3 Indonesian pilchard ${ }^{\mathrm{c}}$ & 0 & Negative & Negative \\
\hline 27 & FH05-085 \#4 Indonesian pilchard ${ }^{\mathrm{C}}$ & 0 & Negative & Negative \\
\hline 28 & FH05-085 \#5 Indonesian pilchard & 0 & Negative & Negative \\
\hline 29 & WA Positive control (cloned PHV373 product) & 12 & Positive (83.0) & Positive \\
\hline
\end{tabular}


ford et al. (2005). DNA extractions from FFPE gill tissue of samples 95-4420 (3 fish), 95-4667 (3 fish), 95-5000 (5 fish), and 95-5135 (4 fish) were performed as described above and tested by PCR. A negative control was included with each PCR that included sterile water instead of template.

Real-time PCR. Real-time PCR was carried out on an iCycler real-time thermal cycler (Bio-Rad). A master mix was prepared as follows: $1 \times$ IQ Sybr Green Supermix (Bio-Rad), 250 nmol primer PHVRltF 5'-AGATACAGTAAATGCTACTCGTTGGTTT-3', 250 nmol primer PHVRltR 5'-CGCGGCGACCAATAAGAC-3', sterile water (to make volume up to $19 \mu \mathrm{l}$ ). Reaction volume was $20 \mu \mathrm{l}$ per tube, consisting of $19 \mu \mathrm{l}$ of master mix and $1 \mu \mathrm{l}$ of template. A negative control was included with each PCR, consisting of $19 \mu$ l of master mix and $1 \mu \mathrm{l}$ of sterile water.

Cycle conditions were $95^{\circ} \mathrm{C}$ for $7 \mathrm{~min}$, followed by 36 cycles of $95^{\circ} \mathrm{C}$ for $15 \mathrm{~s}, 59^{\circ} \mathrm{C}$ for $20 \mathrm{~s}$, and $72^{\circ} \mathrm{C}$ for $25 \mathrm{~s}$, then $72^{\circ} \mathrm{C}$ for $3 \mathrm{~min}, 40$ cycles of $60^{\circ} \mathrm{C}$ for $10 \mathrm{~s}$ with an increment of $0.5^{\circ} \mathrm{C}$ per cycle, and finally held at $4^{\circ} \mathrm{C}$. Data collection and real-time analysis occurred at the annealing step of each cycle $\left(59^{\circ} \mathrm{C}\right)$, and melt curve data collection and analysis occurred at each increment step in the latter 40 cycles. Any samples that recorded a $C_{t}$ value after setting the threshold to 65.0 on the amplification graph and with a melt peak of $83.0^{\circ} \mathrm{C} \pm 1.0^{\circ} \mathrm{C}$ on the melt curve graph were considered to be positive. Samples that failed to record a $C_{t}$ value or failed to produce a specific melt peak were considered to be negative. Some samples were also analyzed by agarose gel electrophoresis for the presence of a band of $80 \mathrm{bp}$.

The clone used as a positive control was also used for determining the sensitivity of the real-time PCR. DNA added for sensitivity testing ranged from $366 \mathrm{ng}^{-1}$ as a neat solution to $3.66 \times 10^{-13} \mathrm{ng}^{-1}$ as a $1: 10^{16}$ dilution. The specificity of the real-time PCR was tested using DNA extractions of 27 known PHV-negative samples including DNA extracts from other piscine herpesviruses, with 2 PHV-positive control samples, as listed in Table 2.

Samples that were prepared and used for PCR were also used for the PHV real-time PCR. Pools of all positive real-time PCR products from samples 95-4667, 95-4420, and 95-5135 (frozen) were purified using DNAce Quick-Clean (Bioline) according to the manufacturer's instructions, and sequenced.

\section{RESULTS}

\section{Histopathology}

Results of histopathological examination of 4 groups of fish collected at different times in relation to the 1995 epizootic are shown in Table 1.

The fish with mild clinical signs (95-5000) showed only slight histological changes. The moribund fish (95-4420) had severe hyperplasia of the gill epithelium, a characteristic sign of PHV infection. Two groups (95-4667 and 95-5135) had no gross or histological lesions, and had either not been exposed to the virus (pre-outbreak) or had recovered from the disease (post-outbreak). It is also possible that some fish had subclinical infection or had not been infected.

\section{ISH}

Two fish groups (95-4667 and 95-5135, Table 3) were negative for PHV by ISH. One fish group (95-4420,

Table 3. Sardinops sagax neopilchardus. Collated results of ISH, PCR, and real-time PCR of pilchards from an epizootic of PHV. Number of fish tested depended on availability of samples. Samples that were positive by real-time PCR were those that recorded a $\mathrm{C}_{\mathrm{t}}$ value and melt peak

\begin{tabular}{|c|c|c|c|c|c|c|}
\hline $\begin{array}{l}\text { Sample } \\
\text { identification }\end{array}$ & $\begin{array}{l}\text { No. of } \\
\text { fish } \\
\text { tested }\end{array}$ & $\begin{array}{l}\text { Collection in } \\
\text { relation to } \\
\text { the epizootic }\end{array}$ & $\begin{array}{c}\text { Method of } \\
\text { preservation }^{\mathrm{a}}\end{array}$ & ISH result & $\begin{array}{c}\text { PHV373 } \\
\text { PCR result }\end{array}$ & $\begin{array}{l}\text { Real-time } \\
\text { PCR result }\end{array}$ \\
\hline $95-4420$ & 6 & During epizootic & Frozen & All strong positive & All strong positive ${ }^{b}$ & All strong positive ${ }^{b}$ \\
\hline $95-4420$ & 3 & During epizootic & FFPE & All strong positive & All negative & All strong positive \\
\hline $95-4667$ & 6 & Pre-epizootic & Frozen & All negative & All negative & All positive \\
\hline $95-4667$ & 3 & Pre-epizootic & FFPE & All negative & All negative & All negative \\
\hline $95-5000$ & 5 & Just before epizootic front & FFPE & All positive & All negative & All strong positive \\
\hline $95-5135$ & 6 & Post-epizootic & Frozen & All negative & All negative & All positive \\
\hline $95-5135$ & 4 & Post-epizootic & FFPE & All negative & All negative & All negative \\
\hline \multicolumn{7}{|c|}{$\begin{array}{l}\text { a Frozen indicates that samples were from fish that were frozen at }-20^{\circ} \mathrm{C} \text {. Other samples were formalin-fixed, paraffin- } \\
\text { embedded (FFPE) tissues that were initially processed for histopathological examination } \\
\text { bA pooled sample of PHV373 PCR products and a pooled sample of real-time PCR products from group 95-4420 were } \\
\text { sequenced to confirm the amplification of PHV }\end{array}$} \\
\hline
\end{tabular}


Table 3) was strongly positive (Fig. 1a \& b). Positive staining was both nuclear and cytoplasmic, which is consistent with virus particles seen by transmission electron microscopy in a previous study (Hyatt et al. 1997).

One fish group (95-5000, Table 3) was mildly ISH positive (Fig. 1c). All positive cells were in close proximity, suggesting that the positive staining was due to staining of riboprobe that had hybridized specifically with target nucleic acid and not background tissue.

Fig. 1d is a negative control slide, and illustrates that any positive staining seen in other samples is likely to be due to hybridization of riboprobe to PHV. All negative controls that were included yielded negative results.

\section{PCR}

The sensitivity of the conventional PCR was determined to be $3.66 \times 10^{-8} \mathrm{ng}$ DNA. We tested 27 known PHV-negative samples including other piscine herpesviruses, identical to those listed in Table 2, to check the specificity of the PHV373 PCR. The 2 known PHVpositive samples were the only samples that produced a positive result (data not shown).
Apparently healthy fish (95-4667 and 95-5135) that were stored at $-20^{\circ} \mathrm{C}$ were negative for PHV by conventional PCR (Table 3). Tissue from moribund fish that were stored at $-20^{\circ} \mathrm{C}(95-4420)$ were strongly positive (Table 3). Agarose gel electrophoresis of these samples is shown in Fig. 2. All other samples were DNA extractions from FFPE tissues, and were negative by PCR (Table 3).

\section{Real-time PCR}

The real-time PCR could detect as few as 776 virus particles calculated after determining the limit of detection of cloned virus to be $3.66 \times 10^{-11} \mathrm{ng}$ DNA. We tested 27 known PHV-negative samples including other piscine herpesviruses (Table 2) to check the specificity of the real-time PCR, and no cross-reactivity was apparent. The 2 samples included as positive controls for the real-time PCR were the only samples that produced a positive result. All samples were further analyzed by agarose gel electrophoresis to confirm the presence of amplified products of the correct size for only the 2 known PHV-positive samples. Bands of $80 \mathrm{bp}$ were only seen for samples 5 and 29 (data not shown).
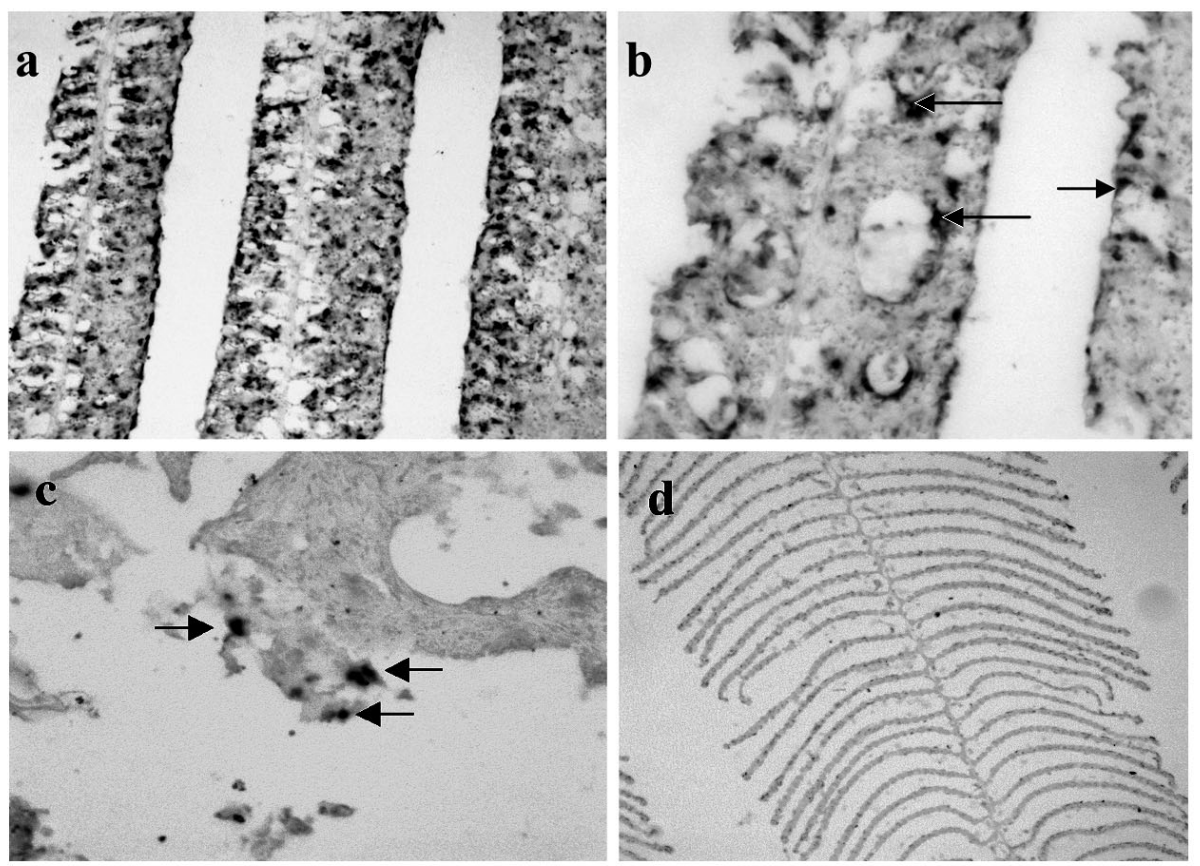

Fig. 1. Sardinops sagax neopilchardus. ISH of gill tissue from an infected and an uninfected pilchard. All sections were counterstained with Bismark brown to illuminate the background tissue. (a) Sample 95-4420, clearly illustrating the distribution of PHV DNA within the tissue. This sample is markedly infected with virus ( $\times 200$ magnification). (b) Sample 95-4420 at higher magnification $(\times 400)$, showing specific staining, both nuclear and cytoplasmic, of the PHV riboprobe to tissue heavily infected with PHV. (c) Sample 95-5000 B4. A few positive cells are seen, indicating a low level of PHV infection ( $\times 400)$. (d) Gill of an unaffected pilchard. Note that the secondary lamellae are separate from each other, indicating normal gill tissue, unlike the fused lamellae seen in (a) and (b). No staining of PHV probe is seen $(\times 400)$ 


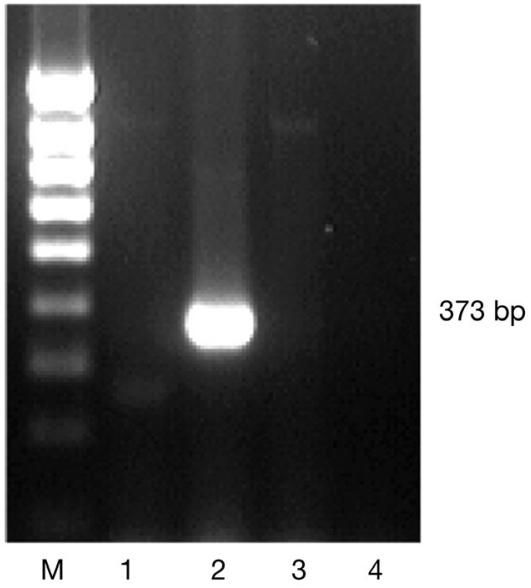

Fig. 2. Sardinops sagax neopilchardus. Agarose gel electrophoresis for PCR of samples from frozen pilchards, collected pre-, during, and post-epizootic of a PHV-outbreak. The only PCR product of the expected size is seen in Lane 2 (373 bp), a sample from a pilchard collected during the outbreak. PCR product was not amplified from samples collected pre- and post-epizootic. M: Hyperladder IV 100 bp MW marker (Bioline); Lane 1: sample 95-4667 collected from frozen pilchards pre-epizootic; Lane 2: sample 95-4420 collected from frozen pilchards during the epizootic; Lane 3 sample 95-5135 collected from frozen pilchards after the mortality front had passed; Lane 4: PCR negative control consisting of water and PCR master mix

Samples tested by the real-time PCR are listed in Table 3. For DNA samples extracted from frozen fish, results were consistent upon repeated testing, with 95-4667 and 95-5135 being positive, and 95-4420 strongly positive. Sequence data from pools of samples 95-4420, 95-4667, and 95-5135 matched the known PHV sequence of 373 bases.

DNA samples that were extracted from FFPE blocks and tested by real-time PCR showed variable results. The heavily affected sample (95-4420) and mildly affected sample (95-5000) were strongly positive (Table 3). Apparently healthy samples (95-4667 and 95-5135) were negative by this testing (Table 3).

\section{DISCUSSION}

Whittington et al. (1997) described a pattern of gill lesions in pilchards caught before, during, and after the epizootic of 1995. They hypothesized that the lesions were due to virus. Because these samples still existed, it was possible to study a range of samples from pre-, just before, during, and post-outbreak for the presence of PHV using the 3 molecular methods developed. Some of the samples available were originally prepared for histopathology and were FFPE. These samples were ideal for ISH but not as suitable for real-time PCR and not suitable at all for the PHV373 PCR. Other samples were from frozen fish and were suitable for PCR and real-time PCR but were unlikely to be suitable for ISH.

Formalin fixation of tissue presents particular challenges for PCR due to the damage it causes to nucleic acids, where cross linkage of nucleic acids to tissue proteins results in fragmentation (Karlsen et al. 1994, Williams et al. 1999, Srinivasan et al. 2002, Bonin et al. 2003, Quach et al. 2004). This was found to be the case in our study. Using the PHV373 PCR on FFPE samples consistently yielded negative results. By contrast, in the real-time PCR, PHV nucleic acid was detected in some of these samples (Table 3). In order to confirm that formalin fixation caused non-detection, repeated testing using heavily infected tissue (95-4420) in the PHV373 PCR demonstrated that PHV was not detectable by this method when FFPE samples were used, but it was detected when frozen fish were used (Table 3). This sample (95-4420) from frozen fish was used as a positive control in other analyses because it yielded a strong positive result; it was negative when tested by PCR as an FFPE sample, suggesting that FFPE samples are not suitable for use in the PHV373 PCR. It could therefore be assumed that positive, but less heavily infected, samples would also yield negative results if they are from FFPE tissues. If the PCR were designed to amplify a fragment smaller than $373 \mathrm{bp}$, there may be a greater chance of detecting PHV.

Although the suitability of some samples was questionable, informative results were obtained, in particular with the real-time PCR. In the real-time PCR, all heavily infected samples (95-4420) were positive (Table 3). Several samples from frozen tissue were negative by PCR and ISH but positive by real-time PCR (Table 3). For FFPE samples, pre- and postoutbreak samples were negative by all methods (Table 3). Table 3 shows that sample preparation greatly affects the ability of the real-time PCR to detect $\mathrm{PHV}$, with virus detected in pre- and post-epizootic samples that were frozen but not when these same samples were FFPE. Samples that were collected just before the mortality front (95-5000) were only available as FFPE and were positive by real-time PCR and mildly positive by ISH (Table 3). Samples collected in the midst of the mortality front produced strong positive results by all 3 methods, except for FFPE samples that were unsuitable for PCR, presumably because the formalin fixative had fragmented the DNA. Crawford et al. (1999) suggested that fixation of tissues in formalin for 24 to $48 \mathrm{~h}$ leads to a reduction of 50 to $75 \%$ in the measurable target copy number.

The real-time PCR demonstrated a 1000-fold increase in sensitivity when compared to conventional 
PCR, with the real-time PCR able to detect $3.66 \times 10^{-11}$ ng DNA and the conventional PCR able to detect only $3.66 \times 10^{-8} \mathrm{ng}$ DNA. False-positives can arise in many ways, including non-specific amplification, contamination, cross-reactions, PCR-induced artifacts, and overamplification (Cha \& Thilly 1993, Morris et al. 2002, Bustin \& Nolan 2004). The possibility that false positives occurred with real-time PCR was reduced by extensive testing undertaken in a survey of current wildstock using real-time PCR (unpubl. data). Unfortunately, no cell culture system has been established for the isolation of PHV to use as a comparison.

Our results showed that virus can be detected at $4 \mathrm{~d}$ prior to the onset of disease. It is not known at this stage if this is newly introduced virus or detection of low levels of virus already present within the population, because no samples were available from the population more than $4 \mathrm{~d}$ before the onset of disease. Furthermore, the fact that PHV was also detected in samples collected post-epizootic does not directly address the question of whether PHV is endemic in pilchard populations. In this case, it could simply reflect the decreasing virus titer in fish that survived the epizootic, or it could be evidence for persistence or latency of PHV in the population of survivors. Dishon et al. (2007) have confirmed that temperature plays an important role in the onset of cyprinid herpesvirus 3 infection in cultured cells, with the virus present but viral gene transcription turned off at non-permissive temperatures, and turned back on upon return to a permissive temperature. Temperature could also be a major factor in the onset of PHV infection.

Ideally, experimental infection of pilchards with PHV would be the best way to generate data on the pathogenesis of the disease. However, difficulties with holding pilchards in captivity currently limit this approach Therefore, as an alternative, it would be interesting to test a range of tissues from fish collected pre-, during, and post-epizootic to determine virus distribution in individual fish, i.e. is PHV primarily concentrated in the gills at all times, or are other tissues also affected? With the development of a more sensitive test that can target PHV at low levels, such a study is now feasible. It is also possible now to use the real-time PCR to quantify the virus particles present within samples and to test pilchards from the current population to determine whether PHV can be considered endemic.

Acknowledgements. We thank Prof. G. E. Wilcox for his assistance in the editing of the manuscript.

Editorial responsibility: John Austin, Oldendorf/Luhe, Germany

\section{LITERATURE CITED}

Bonin S, Petrera F, Niccolini B, Stanta G (2003) PCR analysis in archival postmortem tissues. Mol Pathol 56:184-186

Bustin SA, Nolan T (2004) Pitfalls of quantitative real-time reverse-transcription polymerase chain reaction. J Biomol Tech 15:155-166

Cha RS, Thilly WG (1993) Specificity, efficiency, and fidelity of PCR. PCR Methods Appl 3:518-529

Crawford TB, O'Toole D, Li H (1999) Malignant catarrhal fever. In: Howard JL, Saunders WB (eds) Current veterinary therapy IV: food animal practice. Philadelphia, PA, p 306-309

Crockford M, Jones JB, Crane MSJ, Wilcox GE (2005) Molecular detection of a virus, Pilchard herpesvirus, associated with epizootics in Australasian pilchards, Sardinops sagax neopilchardus. Dis Aquat Org 68:1-5

Dishon A, Davidovich M, Ilouze M, Kotler M (2007) Persistence of cyprinid herpesvirus 3 in infected cultured carp cells. J Virol 81:4828-4836

Gaughan DJ, Mitchell RW, Blight SJ (2000) Impact of mortality, possibly due to herpesvirus, on pilchard Sardinops sagax stocks along the south coast of Western Australia in 1998-99. Mar Freshw Res 51:601-612

Griffin DA, Thompson PA, Bax NJ, Bradford RW, Hallegraeff GM (1997) The 1995 mass mortality of pilchard: no role found for physical or biological oceanographic factors in Australia. Mar Freshw Res 48:27-42

Hyatt AD, Hine PM, Jones JB, Whittington RJ and others (1997) Epizootic mortality in the pilchard Sardinops sagax neopilchardus in Australia and New Zealand in 1995. II. Identification of a herpesvirus within the gill epithelium. Dis Aquat Org 28:17-29

Karlsen F, Kalantari M, Chitemerere M, Johansson B, Hagmar B (1994) Modifications of human and viral deoxyribonucleic acid by formaldehyde fixation. Lab Investig 71: 604-611

Morris DC, Morris DJ, Adams A (2002) Development of improved PCR to prevent false positives and false negatives in the detection of Tetracapsula bryosalmonae, the causative agent of proliferative kidney disease. J Fish Dis 25:483-490

Murray AG, O'Callaghan M, Jones BJ (2003) A model of spatially evolving herpesvirus epidemics causing mass mortality in Australian pilchard Sardinops sagax. Dis Aquat Org 54:1-14

Quach N, Goodman MF, Shibata D (2004) In vitro mutation artifacts after formalin fixation and error prone translesion synthesis during PCR. BMC Clin Pathol 4:1-9

Srinivasan M, Sedmak D, Jewell S (2002) Effect of fixatives and tissue processing on the content and integrity of nucleic acids. Am J Pathol 161:1961-1971

Whittington RJ, Jones JB, Hine PM, Hyatt AD (1997) Epizootic mortality in the pilchard Sardinops sagax neopilchardus in Australia and New Zealand in 1995. I. Pathology and epizootiology. Dis Aquat Org 28:1-16

Williams C, Ponten F, Moberg C, Soderkvist P and others (1999) A high frequency of sequence alterations is due to formalin fixation of archival specimens. Am J Pathol $155: 1467-1471$

Submitted: January 25, 2007; Accepted: July 10, 2008 Proofs received from author(s): September 12, 2008 